\title{
Suppression of Two Tungro Viruses in Rice by Separable Traits Originating from Cultivar Utri Merah
}

\author{
Jaymee R. Encabo, ${ }^{1,2}$ Pepito Q. Cabauatan, ${ }^{1}$ Rogelio C. Cabunagan, ${ }^{1}$ Kouji Satoh, ${ }^{3,4}$ Jong-Hee Lee, ${ }^{5}$ \\ Do-Yeon Kwak, ${ }^{5}$ Teresa B. De Leon, ${ }^{1}$ Reena Jesusa A. Macalalad, ${ }^{1}$ Hiroaki Kondoh, ${ }^{3}$ Shoshi Kikuchi, ${ }^{3}$ \\ and II-Ryong Choi ${ }^{1}$ \\ ${ }^{1}$ Plant Breeding, Genetics, and Biotechnology Division, International Rice Research Institute, DAPO Box 7777, Metro \\ Manila, Philippines; ${ }^{2}$ Microbiology Division, Institute of Biological Sciences, University of the Philippines Los Baños, \\ College, Los Baños, Laguna, Philippines; ${ }^{3}$ Plant Genome Research Unit, Division of Genome and Biodiversity Research, \\ National Institute of Agrobiological Sciences, Kan'non dai 2-1-2 Tsukuba, Ibaraki 305-8602, Japan; ${ }^{4}$ Research Team \\ for Vector-borne Plant Pathogens, National Agricultural Research Center, Tsukuba, Ibaraki, 305-8666, Japan; ${ }^{5}$ Department \\ of Functional Crop Science, National Institute of Crop Sciences, Rural Development Administration, 1085 Neidong, Milyang, \\ Gyeongnam, 627-803, Republic of Korea
}

Submitted 27 January 2009. Accepted 26 May 2009.

Rice tungro disease (RTD) is caused by Rice tungro spherical virus (RTSV) and Rice tungro bacilliform virus (RTBV) transmitted by green leafhoppers. Rice cv. Utri Merah is highly resistant to RTD. To define the RTD resistance of Utri Merah, near-isogenic lines (NIL, $\mathrm{BC}_{5}$ or $\mathrm{BC}_{6}$ ) developed from Utri Merah and susceptible cv. Taichung Native 1 (TN1) were evaluated for reactions to RTSV and RTBV. TW16 is an NIL $\left(B_{5}\right)$ resistant to RTD. RTBV was able to infect both TN1 and TW16 but the levels of RTBV were usually significantly lower in TW16 than in TN1. Infection of RTSV was confirmed in TN1 by a serological test but not in TW16. However, the global gene-expression pattern in an RTSV-resistant NIL $\left(\mathrm{BC}_{6}\right)$, TW16-69, inoculated with RTSV indicated that RTSV can also infect the resistant NIL. Infection of RTSV in TW16 was later confirmed by reverse-transcription polymerase chain reaction but the level of RTSV was considerably lower in TW16 than in TN1. Examination for virus accumulation in another NIL (BC 6 ), TW16-1029, indicated that all plants of TW16-1029 were resistant to RTSV, whereas the resistance to RTBV and symptom severity were segregating among the individual plants of TW16-1029. Collectively, these results suggest that RTD resistance of Utri Merah involves suppression of interacting RTSV and RTBV but the suppression trait for RTSV and for RTBV is inherited separately.

Rice tungro disease (RTD) is a major constraint in production of rice (Oryza sativa L.) in South and Southeast Asia. RTD is caused by two viruses, Rice tungro bacilliform virus (RTBV) and Rice tungro spherical virus (RTSV). RTBV is a plant pararetrovirus belonging to the family Caulimoviridae, genus Tungrovirus, with a circular, double-stranded DNA genome encapsidated in bacilliform particles (Fauquet et al. 2005; Hay et al. 1991; Hull 1996). RTSV is the type member of the Sequiviridae family, genus Waikavirus, having a singlestranded polyadenylated plus-sense RNA genome encapsidated

Corresponding author: Il-Ryong Choi; Telephone: +63-2-580-5600; E-mail: ichoi@cgiar.org

*The $\boldsymbol{e}$-Xtra logo stands for "electronic extra" and indicates that a supplementary table is published online. in polyhedral particles (Fauquet et al. 2005; Hull 1996; Shen et al. 1993). Both viruses are transmitted in a semipersistent manner by a green leafhopper (GLH), Nephotettix virescens Distant (Cabauatan and Hibino 1985; Hibino et al. 1978). RTSV can be independently transmitted by GLH, whereas transmission of RTBV by GLH requires the presence of RTSV or a factor encoded in the RTSV genome (Hibino 1983; Hibino et al. 1987). However, RTBV can be transmitted to rice plants by agroinoculation of a DNA infectious clone (Dasgupta et al. 1991) without RTSV and GLH. RTBV alone may cause symptoms such as yellow-orange discoloration and stunting. RTSV alone does not cause evident symptoms except very mild stunting but it enhances the symptoms caused by RTBV (Hibino et al. 1987).

Cultivar resistance to RTD is an important breeding objective for rice improvement in many Asian countries (Hibino et al. 1990). GLH-resistant cultivars were initially employed to control RTD (Hibino et al. 1987); however, most GLH-resistant cultivars did not show enough durability for continued use in fields (Angeles and Khush 2000; Dahal et al. 1990). Dozens of germplasm sources were found to be highly resistant to RTSV (Hibino et al. 1990), although a distinction between resistance to RTSV and to GLH is yet to be made in RTSVresistant germplasm sources (Sebastian et al. 1996; Shibata et al. 2007; Zenna et al. 2008). Meanwhile, germplasm sources effective to control RTBV practically in fields are still very limited (Hibino et al. 1990; Zenna et al. 2006).

Indonesian cv. Utri Merah is highly resistant to RTSV and tolerant of RTBV (Azzam et al. 2001; Shahjahan et al. 1990). Advanced breeding lines derived from Utri Merah consistently showed low infections with both RTBV and RTSV in several field trials (Cabunagan et al. 1999). Genetic studies showed that RTSV resistance in Utri Merah was determined by two recessive genes, $t s v 1$ and $t s v 2$ (Ebron et al. 1994), and the requirement for the genes to exhibit resistance varied depending on the virus strains (Azzam et al. 2001). RTBV infects Utri Merah but the level of RTBV accumulation in Utri Merah was lower than in susceptible cultivars (Shahjahan et al. 1990). The inheritance patterns of RTBV tolerance in Utri Merah were reportedly controlled by multiple genes (Shahjahan et al. 1990).

Due to the involvement of the two viruses and GLH in the development of RTD, evaluation of rice plants for resistance to RTD is rather complicated. Although the resistance or toler- 
ance of Utri Merah to tungro viruses was reported previously as described above (Azzam et al. 2001, Hibino et al. 1990; Shahjahan et al. 1990), it was also pointed out that characterization of RTD-resistant plants should be based on a comprehensive understanding of host reactions to the individual causal agents considering such factors as i) temporal changes in accumulation of the individual viruses in plants, ii) synergistic and antagonistic interactions between the two viruses, and iii) an influence of insect resistance on GLH behavior and transmission efficiency for the two viruses (Shibata et al. 2007; Sta. Cruz et al. 2003; Zenna et al. 2008).

In order to define the nature of RTD resistance in rice cv. Utri Merah, we observed the temporal changes in symptoms and accumulation of the individual viruses in near-isogenic lines (NIL) derived from Utri Merah for a comparative assessment of resistance to tungro viruses. Our results demonstrated that RTD resistance of Utri Merah involves suppression of both RTSV and RTBV interacting to enhance the symptoms; however, the suppression trait for RTSV and for RTBV is inherited separately.

\section{RESULTS}

\section{Resistance traits from Utri Merah affect} both RTBV and RTSV infections.

To evaluate the effectiveness of RTD resistance from Utri Merah among plants with similar genetic backgrounds, we used NIL derived from Utri Merah and Taichung Native 1 (TN1) throughout the experiments. Two NIL, TW16 $\left(\mathrm{BC}_{5} \mathrm{~F}_{8}\right)$ and TW16-1029 $\left(\mathrm{BC}_{6} \mathrm{~F}_{5}\right)$, were derived from the cross between Utri Merah and TN1 (Fig. 1). Utri Merah and TW16 showed slight stunting after inoculation with RTBV and RTSV but no evident difference in symptoms were observed between them (data not shown). To characterize development of symptoms in NIL by RTD, plants of TN1, TW16, and TW16-1029 were inoculated with both RTSV and RTBV by GLH. Development of symptoms was observed until 35 days postinoculation (dpi). Plants of TN1, TW16, and TW16-1029 inoculated with the two viruses showed signs of slight stunting at $7 \mathrm{dpi}$ (Table 1). Yellow to orange discoloration of leaves was very distinct on TN1 and some plants of TW16-1029 at $14 \mathrm{dpi}$, whereas TW16 remained a normal green color and showed only mild stunting. At 35 dpi, TN1 remained severely stunted and discolored, while TW16 was slightly stunted with a few brownish tips on some leaves (Table 1; Fig. 2A). At 35 dpi, the symptoms developed on TW16-1029 were not uniform: some plants of TW16-1029 were showing leaf discoloration and evident stunting but other plants were showing only mild stunting (Table 1; Fig. 2A). Meanwhile, no apparent phenotypic differences were observed among mockinoculated plants of TN1, TW16, and TW16-1029 during the observation.

The severity of symptoms varied among the plants of TW16-1029 at 35 dpi. In order to see whether the nonuniform

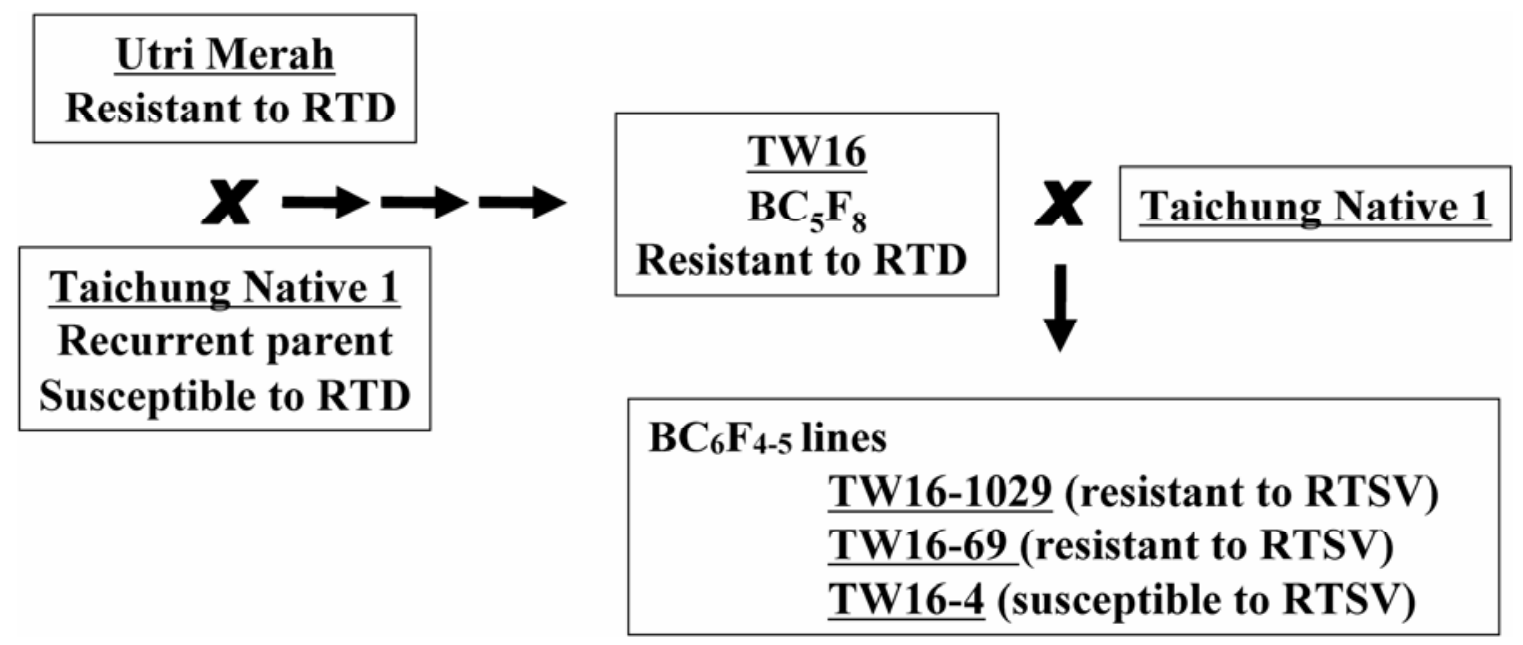

Fig. 1. Near-isogenic lines and their parent cultivars used in this study.

Table 1. Symptom development in TW16, TW16-1029, and Taichung Native 1 (TN1) by infection with tungro viruses

\begin{tabular}{|c|c|c|c|c|c|c|}
\hline \multirow[b]{3}{*}{ Inoculation, time $(\mathrm{dpi})^{\mathrm{b}}$} & \multicolumn{6}{|c|}{ Plants, symptoms ${ }^{\mathrm{a}}$} \\
\hline & \multicolumn{2}{|c|}{ TN1 } & \multicolumn{2}{|c|}{ TW16-1029 } & \multicolumn{2}{|c|}{ TW16 } \\
\hline & Stunting & Leaf yellowing & Stunting & Leaf yellowing & Stunting & Leaf yellowing \\
\hline \multicolumn{7}{|l|}{ GLH } \\
\hline 7 & + & - & + & - & + & - \\
\hline 14 & ++ & + & $++/+$ & $+/ \bullet$ & + & - \\
\hline 21 & ++ & + & $++/+$ & $+/ \bullet$ & + & - \\
\hline 35 & ++ & + & $++/+$ & $+/ \bullet$ & + & - \\
\hline \multicolumn{7}{|l|}{ Agroinoculated } \\
\hline 7 & + & - & + & - & + & - \\
\hline 14 & + & + & + & $+/ \bullet$ & $+/ \bullet$ & - \\
\hline 21 & + & + & + & $+/ \bullet$ & $+/ \bullet$ & - \\
\hline 35 & + & + & + & • & - & - \\
\hline
\end{tabular}

${ }^{\text {a }}$ Stunting was evaluated as $\bullet=$ no visible height reduction, $+=\leq 30 \%$ height reduction, $++=>30 \%$ height reduction, and $/=$ height reduction was not uniform among plants. Leaf yellowing was evaluated as $\bullet=$ no leaf discoloration observed, $+=$ yellow to yellow-orange leaf discoloration observed, and $/=$ leaf yellowing was not uniform among plants.

${ }^{\mathrm{b}}$ Time in days postinoculation (dpi). GLH = green leafhopper inoculated with Rice tungro bacilliform virus (RTBV) and Rice tungro spherical virus and Agroinoculated $=$ agroinoculated with RTBV. 
symptom development within the line was a temporal difference due to recovery, we inoculated the plants of TW16-1029 again with RTBV and RTSV, and observed the symptoms at their maturation. At approximately $110 \mathrm{dpi}, 23$ plants of
TW16-1029 seemed to be divided into two groups: 12 plants with severe stunting and leaf yellowing (Fig. 2C, plants on left) and 11 plants with slight stunting and yellowing (Fig. 2C, plants on right). The 11 plants of TW16-1029 with slight stunt-
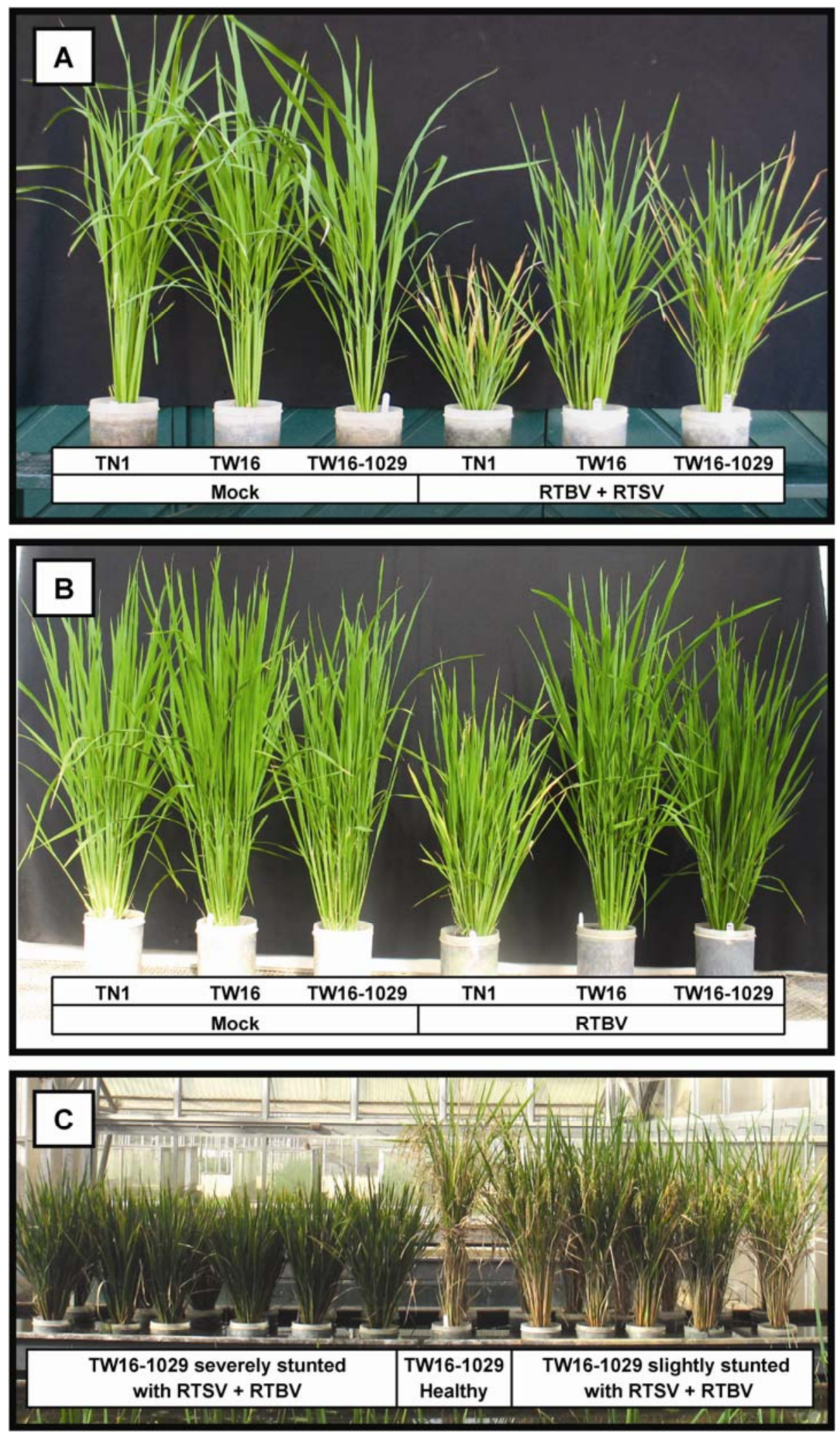

Fig. 2. Symptoms of Utri Merah-derived near-isogenic lines (NIL) and Taichung Native 1 (TN1) infected with tungro viruses. A, Symptoms at 35 days postinoculation (dpi) caused by coinoculation of Rice tungro bacilliform virus (RTBV) and Rice tungro bacilliform virus (RTBV) with green leafhoppers. TW16-1029 shown in the picture is that showing mild stunting. B, Symptoms at 35 dpi caused by agroinoculation of RTBV. C, Segregating symptoms at 110 dpi among TW16-1029 plants coinoculated with RTBV and RTSV. 
ing looked similar to TW16 coinoculated with RTBV and RTSV, whereas the symptoms of 12 plants with severe stunting appeared to be milder than those observed in TN1 infected with RTBV and RTSV. However, some progenies $\left(\mathrm{BC}_{6} \mathrm{~F}_{6}\right)$ from severely stunted TW16-1029 $\left(\mathrm{BC}_{6} \mathrm{~F}_{5}\right)$ showed severe symptoms comparable with those observed in TN1 after coinoculation of RTBV and RTSV (data not shown). The results altogether demonstrated that TW16 was resistant to RTD com- pared with TN1, and that the progeny plants of TW16-1029 were segregating for symptoms after being inoculated with RTSV and RTBV.

To examine the relationship between the variation in symptom severity and the infection of RTBV and RTSV which might be suppressed by resistance from Utri Merah, we examined the temporal changes in the accumulation levels and infection rates of the two tungro viruses in TN1, TW16, and

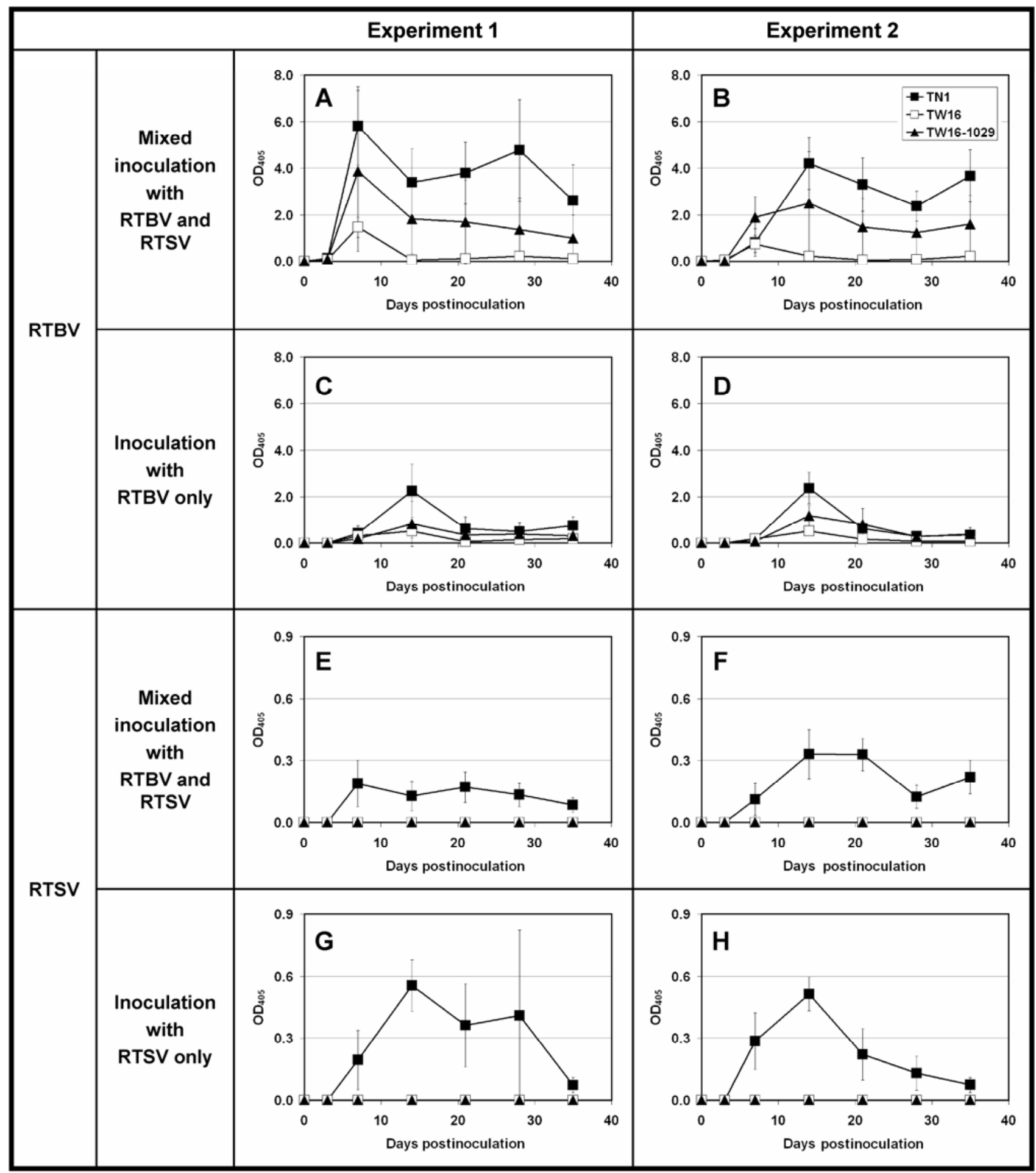

Fig. 3. Temporal changes in relative accumulation levels of Rice tungro bacilliform virus (RTBV) and Rice tungro spherical virus (RTSV) in Taichung Native 1 (TN1), TW16, and TW16-1029. A and B, RTBV levels in plants coinoculated with RTBV and RTSV by green leafhoppers (GLH). C and D, RTBV levels in plants agroinoculated with RTBV. E and F, RTSV in plants coinoculated with RTBV and RTSV by GLH. G and H, RTSV in plants inoculated with RTSV by GLH. The levels of accumulation were normalized to optical density at $405 \mathrm{~nm}$ values corresponding to 20 -fold-diluted extracts. Data points and vertical lines represent the average value and the standard deviation from 2 to 20 samples depending on the numbers of infected plants, respectively. 
TW16-1029 coinoculated with them. For estimation of RTBV levels within the quantifiable range by enzyme-linked immunosorbent assay (ELISA), the optimal dilution rate was set at 200 -fold but leaf extracts were diluted up to 400 -fold due to high virus accumulation levels, particularly in TN1. RTBV accumulation in TN1 reached a maximum at between 7 and 14 dpi (Fig. 3A and B). RTBV levels in TN1 fluctuated during the observation but remained significantly higher than those in TW16 and TW16-1029 after 7 to 14 dpi (Fig. 3A and B; Supplementary Table 1). The rates of infection with RTBV in TN1 were not lower than $80 \%$ at any timepoint after $7 \mathrm{dpi}$. In TW16, RTBV accumulation peaked at 7 dpi with $100 \%$ infection rate (Fig. 3A and $\mathrm{B}$ ). The apparent rates of infection with RTBV in TW16 were often less than 50\% during 14 to 28 dpi. RTBV levels in TW16-1029 peaked at 7 and 14 dpi (Fig. 3A and $\mathrm{B}$ ) but the rates of infection remained high (> 80\%) at 7 dpi onward. The mean levels of RTBV accumulation in TW16-
1029 inoculated with RTBV and RTSV appeared to be intermediate between those of TN1 and TW16 (Fig. 3A and B).

To distinguish whether the intermediate mean level of RTBV accumulation in TW16-1029 resulted from either moderate suppression of RTBV or segregation of RTBV levels within the line, we compared the ranges of absorbance values for RTBV in the individual plants of TW16-1029 with those in the individual plants of their parents, TN1 and TW16. The ranges of RTBV accumulation levels in TN1 were separated from those in TW16 at 14 dpi onward (Fig. 4A and B). The RTBV accumulation levels in TW16-1029 ranged widely, overlapped with the ranges in both TN1 and TW16, and often appeared to segregate into two groups, each at a level similar to that in either TN1 or TW16.

To estimate the RTSV accumulation in the plants simultaneously inoculated with RTBV and RTSV, the optimal dilution rate of extracts was set at 20-fold. Infection of RTSV was not
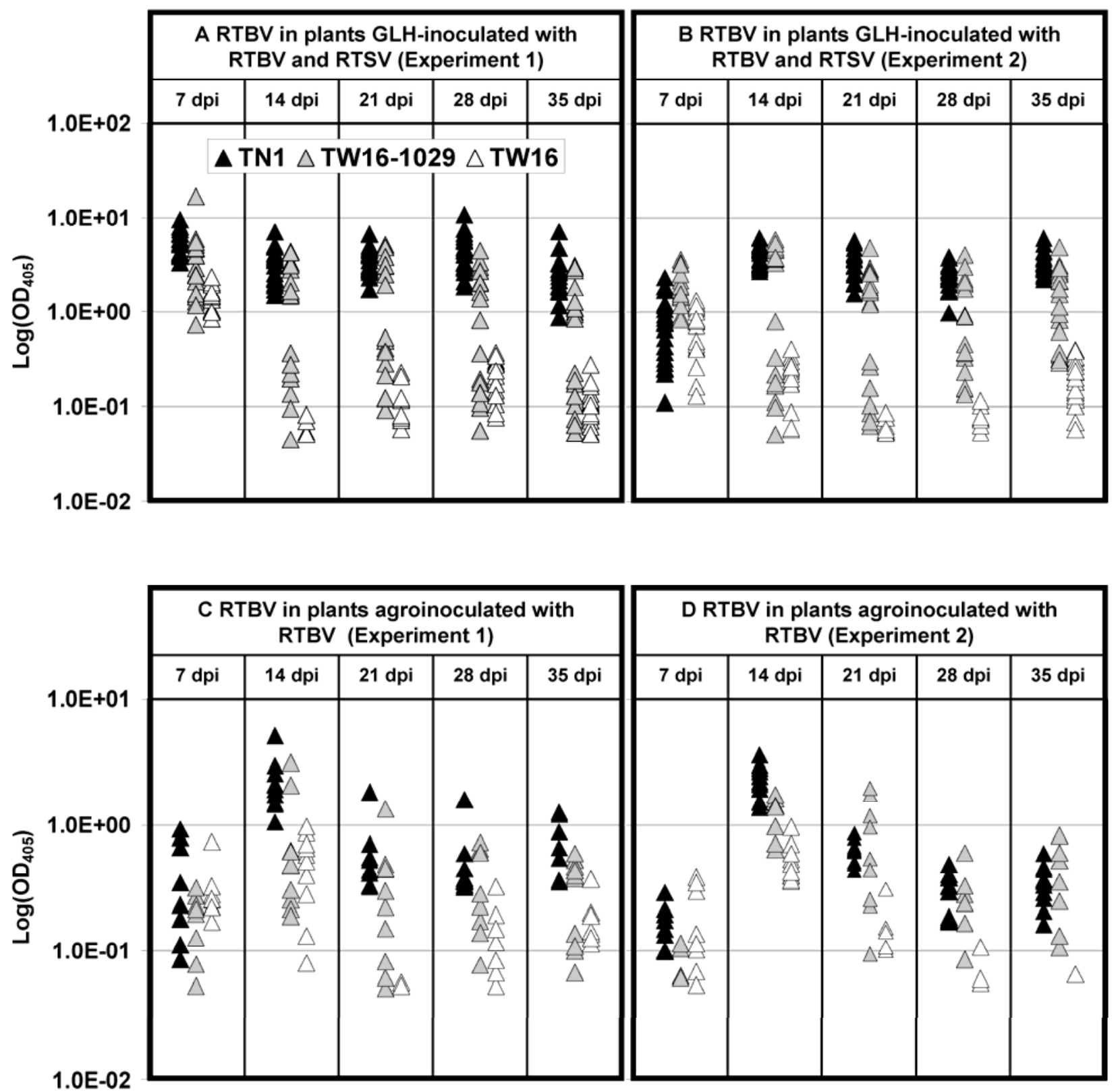

Fig. 4. Distribution of optical density at $405 \mathrm{~nm}\left(\mathrm{OD}_{405}\right)$ values representing the relative accumulation levels of Rice tungro bacilliform virus (RTBV) in individual plants of Taichung Native 1 (TN1), TW16, and TW16-1029. The levels of accumulation were normalized to OD 405 values corresponding to 20fold diluted extracts. A and B, RTBV in plants coinoculated with RTBV and Rice tungro spherical virus (RTSV) by green leafhoppers (GLH). C and D, RTBV in plants agroinoculated with RTBV. 
confirmed by ELISA even with the10-fold diluted extracts from any plants of TW16 and TW16-1029 (Fig. 3E and F). Meanwhile, the accumulation of RTSV in TN1 reached a maximum level at 7 to $14 \mathrm{dpi}$. The apparent infection rates in TN1 were from only 10 to $65 \%$ at any timepoint after $7 \mathrm{dpi}$.

Plants of TW16-1029 segregating for symptoms after coinoculation of RTBV and RTSV (Fig. 2C) were also examined for the accumulation of RTBV and RTSV. At $21 \mathrm{dpi}$, RTSV was not detected by ELISA in any of the plants, indicating that all plants of TW16-1029 were resistant to RTSV. Meanwhile, the levels of RTBV appeared to be associated with symptom severity among the plants of TW16-1029. The levels of RTBV evaluated by ELISA in 10-fold diluted extracts of the plants with severe stunting (Fig. 2C, 12 plants on left) were from 1.2 to 3.0 (mean and standard deviation: $1.9 \pm 0.5$ ), whereas those in the plants slightly stunted (Fig. 2C, 11 plants on right) ranged from 0.1 to 0.6 (mean and standard deviation: $0.3 \pm 0.2$ ).

Resistance of plants to GLH often interferes with the transmission of tungro viruses, making it difficult to distinguish whether the low levels of tungro virus infection in plants are due to resistance to GLH or to the viruses (Shibata et al. 2007; Zenna et al. 2008). To examine the involvement of possible GLH resistance in the low infection rates of tungro viruses in TW16, the levels of antixenosis in TN1 and TW16 were compared with those of GLH-resistant cv. IR62. The results of a free-choice test with RTSV- or RTBV-viruliferous GLH showed that the levels of GLH preference for TN1 and TW16 are virtually the same and significantly lower than for IR62 (data not shown). Meanwhile, despite the significantly low preference of RTSV- or RTBV-viruliferous GLH for IR62, the rates of infection with RTSV and RTBV in IR62 were not significantly different from those in RTD-susceptible TN1 (data not shown). These results suggest that the low incidences of tungro virus infection were not due to GLH resistance in the plants.

Collectively, the results described above suggested that the attenuated tungro symptoms in TW16 derived from Utri Merah are accounted for by suppression of both RTBV and RTSV, and that the suppression trait for RTBV and resistance trait for RTSV are inherited separately.

\section{RTBV is suppressed independently in Utri Merah-derived lines.}

The interaction between RTSV and RTBV might affect virus accumulation and symptom development in plants (Hibino et al. 1988; Shibata et al. 2007). Such interference between viruses may lead to inaccurate evaluation of plant resistance to individual viruses. Thus, to assess the influence of resistance from Utri Merah on the individual tungro virus under the condition devoid of the influence from the other virus, symptom development and virus accumulation were examined in TN1, TW16, and TW16-1029 inoculated with either RTBV or RTSV. The Agrobacterium-mediated method (agroinoculation) was used to prepare plants infected with RTBV only (Dasgupta et al. 1991). Unlike the plants inoculated with both viruses (Fig. 2A), plants infected with RTBV alone showed mild to moderate symptoms (Fig. 2B). Moderate stunting was observed in all three test plants at 7 dpi (Table 1). Typical tungro symptoms were observed on TN1 and some plants of TW16-1029 but not on TW16 at 14 dpi, when the RTBV levels were highest (discussed below). TW16-1029 inoculated with RTBV gradually recovered from leaf discoloration at approximately $21 \mathrm{dpi}$, whereas TN1 retained the discoloration of leaf tips. TW16 remained green with mild stunting at approximately 21 dpi. At the end of the 5-week observation period, TW16 seemed to have fully recovered whereas TN1 showed moderate stunting with a few discolored leaf tips (Fig. 2B). TW16-
1029 showed mild stunting with normal green color and the symptom appeared to be uniform among the plants of TW161029 at 35 dpi.

The optimal dilution rate for ELISA to estimate the RTBV levels in plants agroinoculated with RTBV was 20-fold. Accumulation of RTBV in the test plants reached a maximum at 14 dpi (Fig. 3C and D). The RTBV levels in TW16 were significantly lower than in TN1 at 14 and 28 dpi in both experiments 1 and 2. A significant difference in RTBV levels between TW16-1029 and TN1 was observed only at 14, 21, and 28 dpi in experiment 2. Despite the decrease in virus titer, the rates of infection with RTBV in agroinoculated TN1 were from 70 to $100 \%$ during the observation, whereas those in agroinoculated TW16 varied considerably, from 10 to $100 \%$. The rates of infection with RTBV in agroinoculated TW16-1029 were at least $60 \%$ at 21 dpi onward. Examination of the RTBV accumulation levels in individual plants agroinoculated with RTBV showed a separation of the ranges of RTBV accumulation levels between TN1 and TW16 after 7 dpi (Fig. 4C and D). The levels of RTBV accumulation in TW16-1029 ranged widely but the segregation of RTBV accumulation levels among the plants of TW16-1029 agroinoculated with RTBV was not evident. Therefore, these results indicated that RTBV was independently suppressed in plants with RTD resistance derived from Utri Merah.

\section{Low accumulation of RTSV in Utri Merah-derived lines.}

To evaluate the reaction of Utri Merah-derived NIL to RTSV without the interference of RTBV, TN1, TW16, and TW161029 were inoculated with only RTSV by GLH. None of the plants showed any distinctive symptoms after single inoculation of RTSV. However, RTSV was readily detected in the inoculated plants of TN1 by ELISA. Maximum levels of RTSV in TN1 were observed at approximately 14 dpi (Fig. 3G and $\mathrm{H}$ ). Maximum levels of RTSV in TN1 inoculated with only RTSV (Fig. 3G and H) appeared to be higher than those in TN1 coinoculated with RTBV and RTSV (Fig. 3E and F). The apparent rates of infection with RTSV also seemed to be lower in TN1 plants coinoculated with RTBV and RTSV (10 to $65 \%$ ) than in those inoculated with only RTSV (30 to $100 \%$ ). Meanwhile, RTSV was not detected by ELISA in TW16 and TW16-1029 inoculated with only RTSV. Thus, the results confirmed that the NIL derived from Utri Merah were resistant to RTSV.

In a separate experiment, we examined genes whose expression levels are regulated by RTSV inoculation in two other Utri Merah-derived NIL, TW16-4 and TW16-69, using an oligonucleotide microarray for approximately 21,500 rice genes. Inoculation of RTSV alone by GLH followed by examination of RTSV infection by ELISA showed that TW16-4 was susceptible and TW16-69 was resistant to RTSV, although no symptoms were observed in either plant (data not shown). The result of microarray analysis comparing gene expression levels between the NIL inoculated with virus-free GLH and that inoculated with RTSV-viruliferous GLH showed that the expression levels of 68 genes were significantly changed in TW16-4 by RTSV infection at 7 dpi (Fig. 5). The expression levels of 104 genes were significantly changed in TW16-69 by inoculation with RTSV although RTSV was not detected in any plants of TW16-69 by ELISA. Among the genes responding to RTSV inoculation, 46 genes appeared to be regulated similarly in both TW16-4 and TW16-69 (Table 2). Gene functions described in the Rice Annotation Project database (Rice Annotation Project 2008) indicated that many of the commonly regulated genes are likely to be involved in responses to biotic and abiotic stresses. For example, putative droughtresponsive element-binding protein (DREB) genes (AK062422 
and AK105599) were reported to be highly induced by drought, high salinity, and cold stresses (Dubouzet et al. 2003; Ito et al. 2006). WRKY transcription factors (AK058773 and AK108657) are a group of transcription regulators involved in defense systems responding to pathogens (Chujo et al. 2008; Dong et al. 2003). Cytochrome P450 protein (AK067007) is also known as OsABA8ox1, which was highly induced by submergence stress (Saika et al. 2007). NAC transcription factor (AK067690) was highly induced by Magnaporthe grisea infection (Lin et al. 2007). A homologue of AP2 domain-containing protein (AK062882) in Arabidopsis was reported to be involved in cold, salt, drought, and disease stress responses (Feng et al. 2005; Gutterson and Reuber 2004). Thus, the results of microarray analysis implied that RTSV may have infected TW16-69 at a level undetectable by ELISA, and activated the expression of stress-related genes.

To verify whether the induced expression of commonly regulated genes by inoculation with RTSV was indicative of responses to virus infection in Utri Merah-derived NIL, we examined the time-course expression patterns of nine of the genes (Table 2) in TW16 agroinoculated with RTBV. We used the plants infected with RTBV but not those infected with RTSV for the experiment, because the infection of RTBV but not that of RTSV was readily detectable in TW16. Although the levels of expression varied depending on the genes and the timings of sampling, genes for DREB 1B (AK062422), allyl alcohol dehydrogenase (AK109382), and a protein similar to a gene-silencing regulator (AK062671) showed an inducible expression pattern by RTBV infection in both TN1 and TW16 (Fig. 6). It was reported that the product of a gene in Nicotiana tabacum homologous to the gene for gene-silencing regulator AK062671 interacts with HC-Pro of Tobacco etch virus to suppress gene silencing (Anandalakshmi et al. 2000). An alcohol dehydrogenase similar to AK109382 is involved in the defense response against $M$. grisea infection (Lu et al. 2004). The results suggested that these stress-related genes commonly

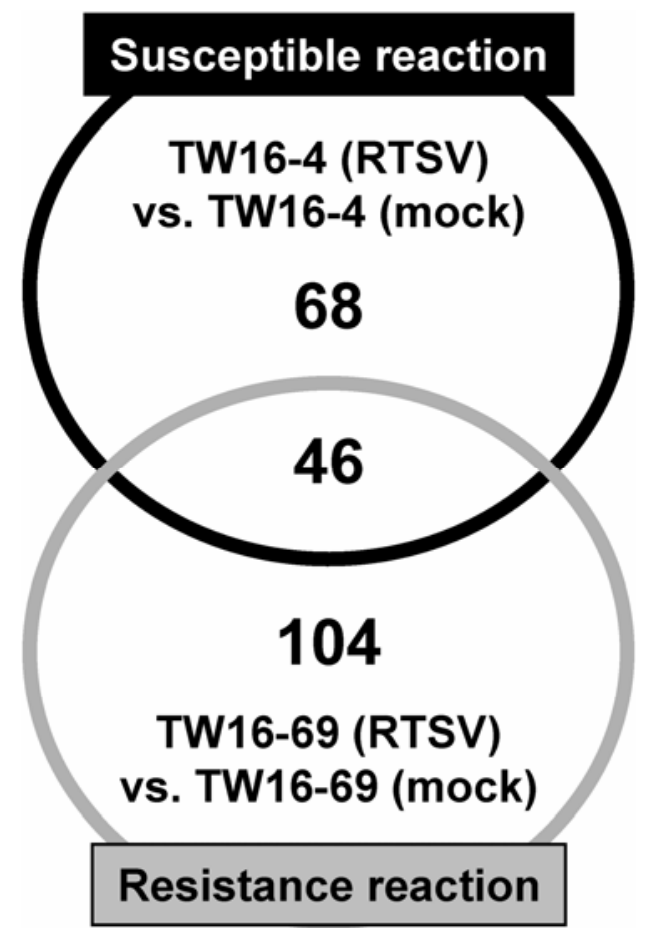

Fig. 5. Numbers of genes whose expression levels were significantly changed by Rice tungro spherical virus (RTSV) inoculation in RTSVsusceptible TW16-4 $(n=68)$, resistant TW16-69 $(n=104)$, and both lines $(n=46)$. respond to infections with different viruses and that, conversely, virus infection in Utri Merah-derived NIL can be represented by the induced expression of such stress-related genes.

Based on the results of host gene expression analyses, which implied the infection of RTSV in Utri Merah-derived resistant NIL, we attempted to detect RTSV in plants by reverse-transcription polymerase chain reaction (RT-PCR). An initial attempt with RT-PCR for the RTSV genome segments using RNA samples extracted from whole-leaf tissues with several different pairs of primers failed to detect RTSV in TW16 inoculated with RTSV. Because the failure could be due to the nonuniform distribution of virus within infected plants, another attempt with RT-PCR for the RTSV genome segments was made using RNA samples prepared from divided leaves of TN1 and TW16 plants at 9 and 12 dpi (Fig. 7A). A DNA fragment of expected size (787 bp) corresponding to the targeted region of the RTSV genome was amplified from all the samples of TN1 plants inoculated with RTSV (Fig. 7B). The levels of RTSV in TN1 judged by the band intensities appeared to vary depending on tissue fragments and sampling timings. The RTSV-specific band was also detected in a few samples prepared from the leaf segments of TW16 plants at 9 and $12 \mathrm{dpi}$, although the levels of RTSV in TW16 were markedly lower than those observed in TN1. Meanwhile, RTSV was not detected from any mock-inoculated plants of TN1 and TW16 by RT-PCR, and RTSV was undetectable from any plants of TW16 by ELISA. Because the RNA samples were prepared from the leaves that emerged after RTSV inoculation by GLH, the results suggested that RTSV systemically infected TW16 but accumulated at a level considerably lower than that in TN1 due to the resistance trait from Utri Merah.

In order to examine whether the resistance modes of Utri Merah against RTSV and RTBV were functioning at the cellular level or at the level of whole plant (Kang et al. 2005), the distribution of RTSV and RTBV in infected tissues was examined by immunological tissue blotting (Lin et al. 1990). Examination of cross-sections of leaf tissues from infected plants showed that RTBV was readily detectable in TN1 plants agroinoculated with RTBV (Fig. 8B) and those coinoculated with RTBV and RTSV by GLH (Fig. 8H). The presence of RTBV protein was detected as purple color products in the tissues. The reaction was especially intense at the vascular bundles. The reaction for RTBV in TW16 appeared to be much weaker in TW16 agroinoculated with RTBV, although intensive color reaction was observed at most vascular bundles (Fig. 8C). Distribution of RTBV in plants agroinoculated with RTBV indicated that RTBV systemically infected TW16 by agroinoculation of RTBV but the accumulation of RTBV was lower than that observed in TN1. Meanwhile, distribution of RTBV in TW16 coinoculated with RTBV and RTSV was limited to a few vascular bundle regions, suggesting that the RTBV movement may be inhibited in TW16 when coinoculated with RTBV and RTSV (Fig. 8I). RTSV was also detected in the vascular bundles of TN1 plants coinoculated with RTBV and RTSV (Fig. 8K) and those inoculated with RTSV alone (Fig. $8 \mathrm{E})$, although the intensity of reactions were weaker than that observed for RTBV. We were not able to observe any intensive color development for RTSV in any cross-section tissues of TW16 (Fig. 8F and L). Thus, the results implied that resistance of TW16 against RTSV is largely functioning at the cellular level and not by inhibition of virus movement.

\section{DISCUSSION}

Resistance to tungro viruses is a rare trait among rice germplasm sources (Azzam and Chancellor 2002; Hibino et al. $1988,1990)$. Evaluation for resistance to tungro viruses often 
requires laborious processes because the consequences from resistance traits for the viruses and those for the insect vectors are often indistinguishable and the levels of two interacting viruses in a plant are difficult to estimate (Sebastian et al. 1996; Shibata et al. 2007; Zenna et al. 2008). Comparisons of accumulation levels of RTBV and RTSV in TN1 and TW16 inoculated only with a single virus (Fig. 2) and detection of RTSV in TW16 (Fig. 7B) demonstrated that resistance from Utri Merah is able to suppress the accumulation of both viruses.

Resistance in another accession of Utri Merah to the same RTSV isolate used in this study is reportedly governed by a single recessive gene (Azzam et al. 2001; Ebron et al. 1994). Recessive resistance to viruses in plants is often ascribed to the lack of a specific host factor required by the virus to complete its infection cycle (Diaz-Pendon et al. 2004). Recessive resistance associated with a specific allele for translation initiation factor eIF(iso) $4 \mathrm{G}$ was also reported for the interaction between rice cv. Gigante and Rice yellow mottle virus (Albar et al. 2006). Thus, the low or lack of expression of such host factors essential for virus infection might also be involved in the resistance of Utri Merah to RTSV. Genetic analysis of RTSV resistance in Utri Merah now being conducted suggests that RTSV resistance may be associated with an eIF4G gene located in chromosome 7 (J.-H. Lee and I.-R. Choi, unpublished results).

Shahjahan and associates (1990) suggested that RTBV resistance of Utri Merah was controlled by an incompletely dominant gene or multiple genes, based on the observation that the mean accumulation levels of RTBV in the progenies from the cross between Utri Merah and TN1 were intermediate between those of the parental plants. Similarly, in this study, the mean accumulation levels of RTBV in the progeny line TW16-1029 produced by the cross between TN1 and TW16 were intermediate between those of the parental plants (Fig. 3). However, the considerable variation in RTBV accumulation levels, often

Table 2. Genes whose expression levels were significantly changed in both TW16-4 (susceptible to RTSV) and TW16-69 (resistant to RTSV) by inoculation with Rice tungro spherical virus (RTSV)

\begin{tabular}{|c|c|c|c|}
\hline \multirow[b]{2}{*}{ Accession no. } & \multirow[b]{2}{*}{ Description $^{b}$} & \multicolumn{2}{|c|}{ Average $\log _{10}$ ratio in ${ }^{a}$} \\
\hline & & TW16-4 & TW16-69 \\
\hline AK105331 & Conserved hypothetical protein & 1.091 & 1.024 \\
\hline AK062422 & Putative DRE-binding protein $1 \mathrm{~B}^{\mathrm{c}}$ & 0.982 & 0.985 \\
\hline AK106404 & Cytochrome P450 family protein & 0.977 & 1.050 \\
\hline AK058773 & Transcription factor WRKY09 & 0.936 & 0.845 \\
\hline AK062882 & AP2 domain-containing protein & 0.910 & 1.055 \\
\hline AK 103060 & Hypothetical protein & 0.875 & 0.837 \\
\hline AK061602 & ZIM domain-containing protein ${ }^{c}$ & 0.848 & 0.909 \\
\hline AK109382 & Allyl alcohol dehydrogenase ${ }^{c}$ & 0.847 & 0.838 \\
\hline AK071734 & bHLH domain-containing protein & 0.838 & 0.948 \\
\hline AK108001 & Hypothetical protein & 0.811 & 0.748 \\
\hline AK111852 & Calcium-binding protein & 0.802 & 0.756 \\
\hline AK105599 & DRE-binding protein $1 \mathrm{~A}^{\mathrm{c}}$ & 0.801 & 0.934 \\
\hline AK068115 & Harpin-induced 1 domain-containing protein ${ }^{\mathrm{c}}$ & 0.775 & 0.578 \\
\hline AK104991 & Conserved hypothetical protein & 0.766 & 0.780 \\
\hline AK107937 & Zinc finger, RING-type domain-containing protein & 0.764 & 0.738 \\
\hline AK062811 & Hypothetical protein & 0.730 & 0.725 \\
\hline AK109131 & Hypothetical protein & 0.721 & 0.626 \\
\hline AK070649 & ZIM domain-containing protein & 0.721 & 0.711 \\
\hline AK071585 & Putative protein kinase $\mathrm{c}^{\mathrm{c}}$ & 0.708 & 0.762 \\
\hline AK062671 & Protein similar to gene silencing regulator and Avr9/Cf-9 rapidly elicited protein ${ }^{c}$ & 0.699 & 0.724 \\
\hline AK067456 & Zinc finger, RING-type domain-containing protein & 0.681 & 0.642 \\
\hline AK067971 & Hypothetical protein & 0.663 & 0.646 \\
\hline AK107989 & Hypothetical protein & 0.661 & 0.555 \\
\hline AK067779 & Hypothetical protein & 0.659 & 0.489 \\
\hline AK067690 & NAC transcription factor ${ }^{c}$ & 0.647 & 0.604 \\
\hline AK062711 & Flagellar calcium-binding protein & 0.637 & 0.650 \\
\hline AK105196 & Putative protein kinase ${ }^{c}$ & 0.627 & 0.520 \\
\hline AK 106003 & Zinc finger, RING-type domain-containing protein & 0.624 & 0.575 \\
\hline AK 105323 & Hypothetical protein & 0.616 & 0.671 \\
\hline AK108657 & Transcription factor similar to WRKY 48 & 0.615 & 0.530 \\
\hline AK111571 & Myb family transcription factor & 0.586 & 0.571 \\
\hline AK067181 & Zinc finger, RING-type domain-containing protein & 0.547 & 0.451 \\
\hline AK109607 & Putative protein kinase & 0.545 & 0.524 \\
\hline AK064058 & Hypothetical protein & 0.523 & 0.496 \\
\hline AK063898 & Hypothetical protein & 0.510 & 0.535 \\
\hline AK071729 & Hypothetical protein & 0.506 & 0.431 \\
\hline AK067104 & Hypothetical protein & 0.505 & 0.574 \\
\hline AK 103002 & Hypothetical protein & 0.494 & 0.542 \\
\hline AK067007 & Cytochrome P450 family protein & 0.494 & 0.450 \\
\hline AK069247 & Hypothetical protein (DUF563) & 0.481 & 0.635 \\
\hline AK072758 & EF-Hand type domain-containing protein & 0.467 & 0.402 \\
\hline AK063743 & Protein similar to EL2 & 0.462 & 0.461 \\
\hline AK100032 & $\beta$-glucan binding protein & 0.452 & 0.468 \\
\hline AK105493 & No apical meristem (NAM)/OsNAC4 protein & 0.429 & 0.447 \\
\hline AK112100 & Protein similar to DEM2 & 0.386 & 0.473 \\
\hline AK068312 & Pathogenesis-related transcription factor & 0.371 & 0.406 \\
\hline
\end{tabular}


accompanying evident segregation to the parental levels, among the individual plants of TW16-1029 (Fig. 4) is suggestive of segregation of RTBV resistance, although it is uncertain how many genes are involved in suppression of RTBV in Utri Merah-derived NIL. Indistinct segregation of the RTBV accumulation levels among the individual plants of TW16-1029 was also observed, especially in those agroinoculated with RTBV when the virus titers were relatively low. The lack of apparent segregation for RTBV levels among the individual plants of TW16-1029 could be due to the limited sensitivity of ELISA to detect minute differences among the low virus accumulation levels.

Previous reports demonstrated that Utri Merah has resistance traits affecting the infections of both RTBV (Shahjahan et al. 1990) and RTSV (Azzam et al. 2001; Ebron et al. 1994). However, it had been uncertain whether the two viruses were inhibited by separate resistance traits of Utri Merah. In this study, the levels of RTSV resistance in TW16 and TW16-1029 estimated by ELISA were indistinguishable, because RTSV was not detected in any plants of either line (Fig. 3). Meanwhile, the levels of RTBV in TW16-1029 varied between the levels similar to those observed in TN1 and those in TW16 (Fig. 4). The simplest interpretation of these results might be that the trait of resistance of TW16 to RTSV and to RTBV was independently passed on to TW16-1029. Such independent inheritance patterns of RTBV and RTSV resistance traits were also observed in two RTD-resistant cultivars, Matatag 1 and Matatag 2, derived from Utri Merah (Khush et al. 2004). Both Mata- tag 1 and Matatag 2 exhibit similar levels of field resistance to RTD, although only Matatag 1 is resistant to RTSV (data not shown).

It is still unclear how RTBV and RTSV synergistically enhance symptoms in rice. The severity of symptoms in TW161029 by coinoculation of RTBV and RTSV was seemingly associated with the levels of RTBV in the plant because RTSV was not detected in the segregating plants of TW16-1029 by ELISA (Fig. 2C). Thus, the symptom severity in plants by RTD is likely associated with the level of RTBV per se, although the low levels of RTSV may also contribute to enhancement of symptoms directly by affecting host gene expression or indirectly by increasing the level of RTBV in plants. In addition, the difficulty in quantitatively associating the symptom variation with virus accumulation in plants inoculated with RTBV and RTSV still leaves open the possibility that other traits to suppress symptoms in rice may be involved (Shibata et al. 2007).

Examination for changes in expression of stress-related genes in both susceptible and resistant NIL derived from Utri Merah in response to RTSV inoculation (Table 2) led us to conclude that RTSV can systemically infect TW16, though the accumulation of RTSV in the plants was barely detectable even by RT-PCR (Fig. 7). RTBV- and RTSV-inducible expression patterns of genes for gene-silencing regulator AK062671, allyl alcohol dehydrogenase (AK109382), and DREB 1B (AK062422) (Fig. 6) indicate that these are associated with common responses to tungro virus infection in rice. The involvement of these tungro virus-responsive genes in the virus

\begin{tabular}{|c|c|c|c|}
\hline \multirow{3}{*}{ Gene } & \multirow{3}{*}{ Treatment } & TW16 & TN1 \\
\hline & & \multicolumn{2}{|c|}{ Days postinoculation } \\
\hline & & $3,7,14,21$ & $3,7,14,21$ \\
\hline \multirow{2}{*}{$\begin{array}{l}\text { Gene silencing } \\
\text { regulator } \\
\text { (AK062671) }\end{array}$} & Mock & & - \\
\hline & RTBV & $\therefore-$ & $-\quad--$ \\
\hline \multirow{2}{*}{$\begin{array}{l}\text { Allyl alcohol } \\
\text { dehydrogenase } \\
\text { (AK109382) }\end{array}$} & Mock & & \\
\hline & RTBV & $\rightarrow-\cdots$ & --- \\
\hline \multirow{2}{*}{$\begin{array}{c}\text { DREB 1B } \\
\text { (AK062422) }\end{array}$} & Mock & --- & - \\
\hline & RTBV & - & - 존옹 \\
\hline \multirow{2}{*}{$\begin{array}{c}\text { Rubisco } \\
\text { (AK058623) }\end{array}$} & Mock & ---0 & ---- \\
\hline & RTBV & ---2 & ---- \\
\hline \multirow{2}{*}{$\begin{array}{l}\text { 18s rRNA } \\
\text { (AF069218) }\end{array}$} & Mock & ---- & --- \\
\hline & RTBV & --- & --- \\
\hline
\end{tabular}

Fig. 6. Time-course expression of genes responding to Rice tungro bacilliform virus (RTBV) infection in Taichung Native 1 (TN1) and TW16 agroinoculated with RTBV. 
resistance in TW16 is uncertain, although the expression levels of DREB 1B in mock- and RTBV-inoculated plants of TW16 seemed to be higher than in the corresponding plants of TN1.

Distribution patterns of RTBV and RTSV in TW16 examined by immunological tissue blotting (Fig. 8) gave insights into how resistance of Utri Merah functions against the two viruses. It appeared that the movement of RTBV was inhibited when coinoculated with RTSV, whereas it was not in TW16 agroinoculated with RTBV alone. The cause of such a difference may be the difference in inoculum source: inoculation of RTBV by GLH only lasted for 1 day, whereas the RTBV genome is supposed to be continually produced from the site of agroinoculation. Otherwise, the interaction between RTSV and RTBV may shut off a resistance mechanism involving movement inhibition in TW16 coinoculated with both viruses. Meanwhile, we were not able to find evidence for resistance of Utri Merah (TW16) functioning against RTSV movement. RTSV may be suppressed at the cellular level, probably by the lack of host factors necessary for RTSV replication, such as translation initiation factors (Albar et al. 2006; Kang et al. 2005) (J.-H. Lee and I.-R. Choi, unpublished results). The discrepancy between detection of RTSV by RT-PCR and that by immunological methods in TW16 could be due to the difference in sensitivity of the two methods or the difference between the accumulation pattern of RTSV protein and that of RTSV RNA in TW16.

The results of this study collectively suggest that attenuated symptoms in Utri Merah-derived NIL by RTD are accounted for by the suppressed accumulation of RTBV and RTSV, which are synergistically interacting for symptom enhancement, and that the trait of resistance to RTBV and to RTSV originating in Utri Merah can be independently passed on to progenies. The information described in this study is indispensable for the characterization of Utri Merah-derived plants for reactions to tungro viruses to identify genes conferring resistance to two tungro viruses which, in turn, facilitates the improvement of rice cultivars for tungro resistance.

\section{MATERIALS AND METHODS}

Plant materials.

TW16 is a backcross line $\left(\mathrm{BC}_{5} \mathrm{~F}_{8}\right)$ developed from the donor cv. Utri Merah (International Rice Germplasm Collection accession number 16682) and the recurrent parent TN1 (Fig. 1). TN1 is susceptible to both RTSV and RTBV, whereas Utri Merah is resistant to RTD. TW16-1029, TW16-69, and TW164 are NIL $\left(\mathrm{BC}_{6} \mathrm{~F}_{4-5}\right)$ developed by crossing TW16 and TN1 (Fig. 1). TW16, TW16-1029, and TW16-69 are resistant to RTSV, whereas TW16-4 is susceptible to RTSV based on evaluation by ELISA (Bajet et al. 1985). IR62 was used as a control for GLH resistance.

\section{Virus inoculation.}

RTSV strain A and RTBV common strain (Cabauatan et al. 1995) maintained in TN1 were used as sources of inoculum. Insect inoculation of viruses to plants was done by the tube method as described by Cabauatan and associates (1995). GLH

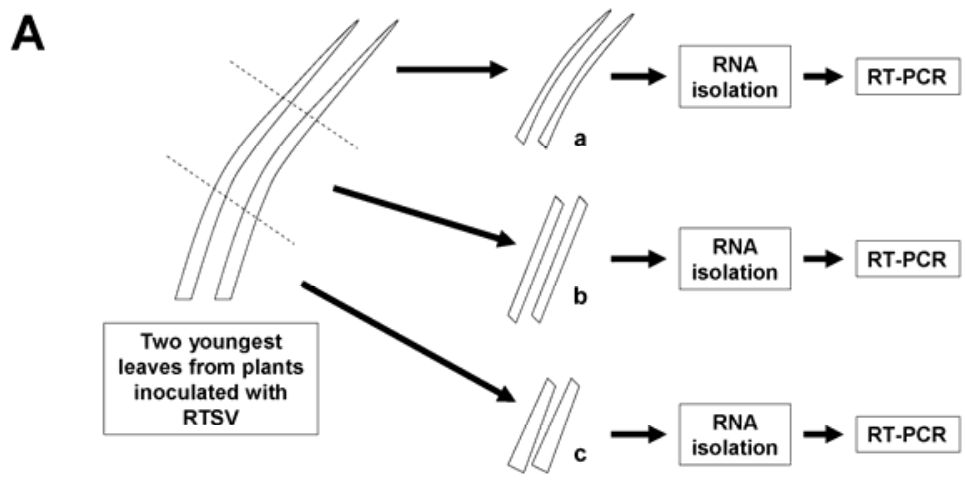

B

TN1 with RTSV TW16 with RTSV Plant 1 Plant 2 Plant 3 Plant 1 Plant 2 Plant 3 a b c a b c a b c a b c a b c a b c

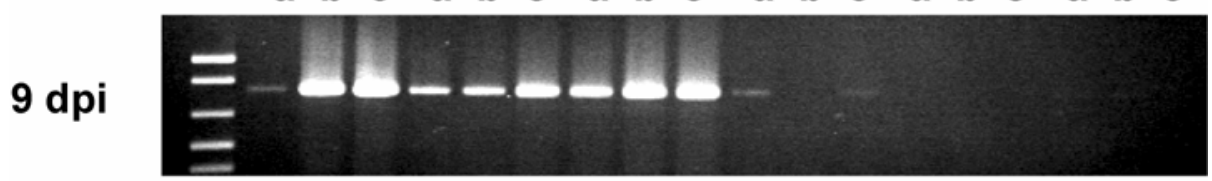
TN1 with RTSV TW16 with RTSV $\frac{\text { Plant } 1}{\text { a b c }} \frac{\text { Plant } 2}{\text { a b c }} \frac{\text { Plant } 3}{\text { a b c }} \frac{\text { Plant } 1}{\text { a b c }} \frac{\text { Plant } 2}{\text { a b c }} \frac{\text { Plant } 3}{\text { a b c }}$

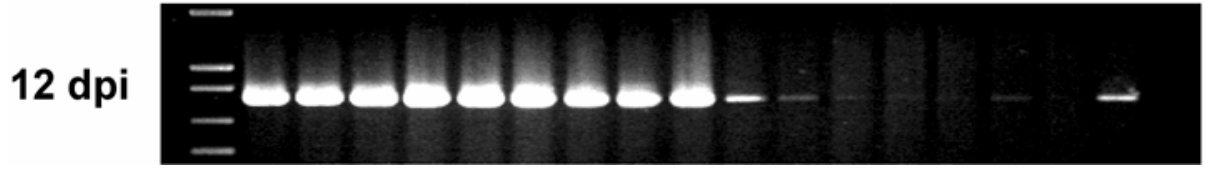

Fig. 7. Detection of Rice tungro spherical virus (RTSV) by reverse-transcription polymerase chain reaction (RT-PCR) in Taichung Native 1 (TN1) and TW16 inoculated with RTSV by green leafhoppers. A, Scheme of RNA sample preparation from inoculated plants. B, RTSV-specific DNA fragments amplified by RT-PCR using RNA samples from plants at 9 and 12 days postinoculation (dpi). 
were given a 3-day acquisition access period to RTBV- or RTSV-infected plants and were allowed an inoculation access period of $24 \mathrm{~h}$ to 14-day-old plants at five insects per plant. Inoculated plants were maintained in the greenhouse of the International Rice Research Institute (IRRI). To prepare plants infected with RTBV alone, plants were inoculated with the RTBV infectious clone through the Agrobacterium-mediated method (Dasgupta et al. 1991; Sta. Cruz et al. 1999). The bacterial suspension $(200 \mu \mathrm{l})$ was injected into each 14-day-old plant at the base of the stem. Plants were inoculated with Agrobacterium sp. strain GV3850 containing the RTBV infec- tious clone (pRTRB1162), whereas the Agrobacterium devoid of the RTBV infectious clone was used to prepare mockinoculated plants. Agroinoculated plants were maintained under natural lighting conditions and temperature ranging from 27 to $29^{\circ} \mathrm{C}$ at the containment facility of IRRI.

\section{Estimation of virus accumulation.}

The relative levels of tungro virus accumulation in plants were estimated as detailed by Shibata and associates (2007) using the absorbance values for the viruses in plants obtained by ELISA (Bajet et al. 1985). Fourteen-day-old plants were

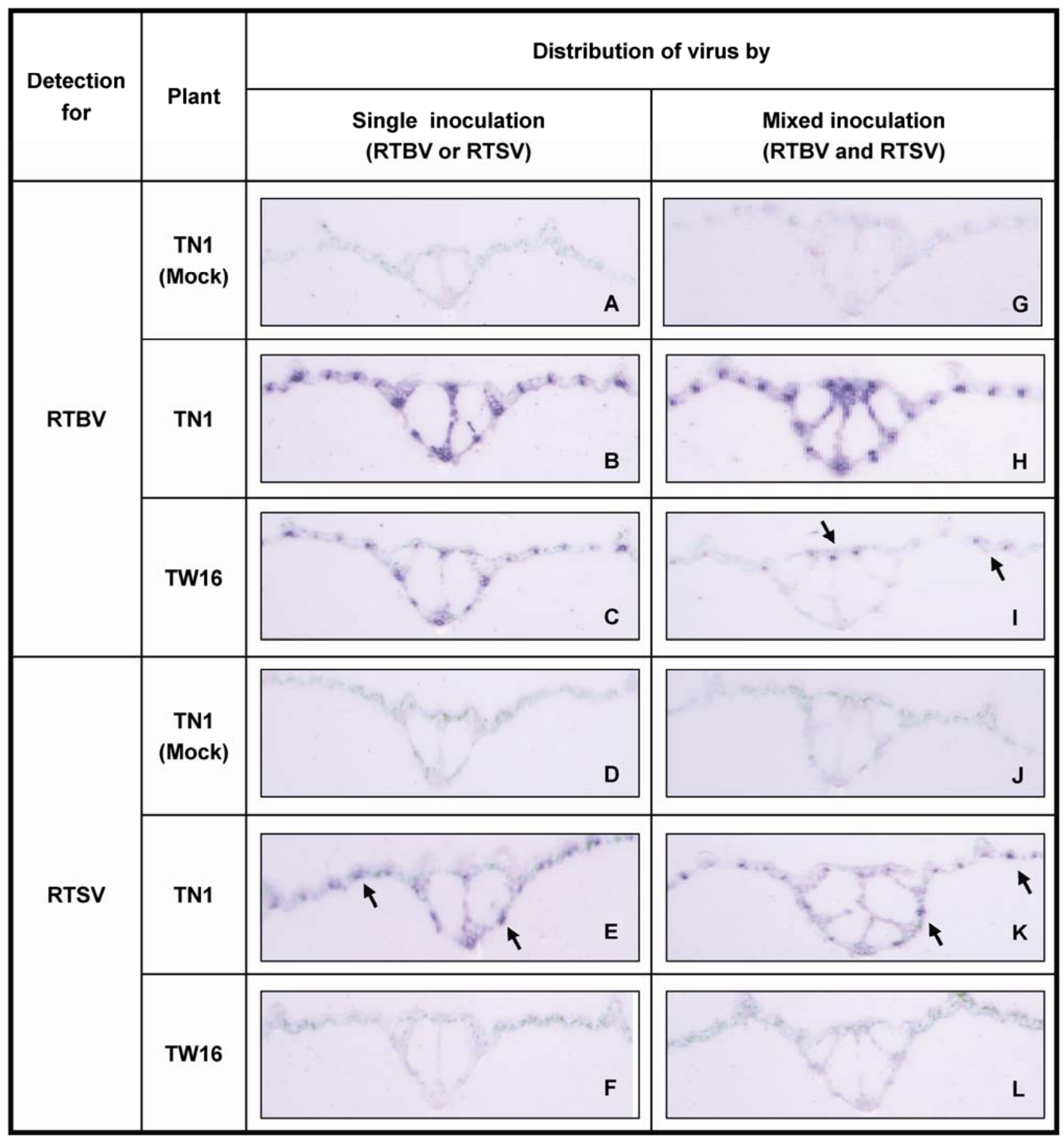

Fig. 8. Detection of Rice tungro bacilliform virus (RTBV) and Rice tungro spherical virus (RTSV) by direct tissue blotting immunoassay. A, G, D, and J, Mock-inoculated Taichung Native 1 (TN1) plants for the corresponding inoculation treatments. B, C, H, and I, Distribution of RTBV and E, F, K, and $\mathbf{L}$, RTSV in leaf cross-sections of plants agroinoculated with RTBV (B and C), insect-inoculated with RTSV only (E and F), and insect-inoculated with RTBV and RTSV $(\mathrm{H}, \mathrm{I}, \mathrm{K}$, and L) at $\times 56$ magnification. Leaf samples were taken between 12 and 14 days postinoculation. Each panel shows a representative result from multiple section samples examined for the corresponding treatment. Arrows in some panels are to indicate colored spots by the reaction. 
inoculated with the viruses as described above. Two fully expanded leaves from 10 to 20 individual plants were collected at $0,3,7,14,21,28$, and $35 \mathrm{dpi}$. Because the virus accumulation level in a plant often exceeds the dynamic range of ELISA, optimum sample dilution rates were determined to ensure that the amount of virus measured was within the quantifiable range. Optimal sample dilutions giving absorbance values within the quantifiable range were initially determined using serially diluted extracts of TN1 plants infected with RTSV and RTBV. Based on the initial optimization results, three to four leaf extracts diluted from 10 to 60 times, including the one at the optimal dilution rate (discussed above), were prepared from the plants singly infected with RTSV or RTBV, whereas three to four leaf extracts diluted from 10 to 400 times, including the one at the optimal dilution rate, were made from the plants inoculated with both RTSV and RTBV. The diluted leaf extracts were subjected to ELISA. Plants for which 10-fold-diluted extracts showed an absorbance value higher than 0.1 were considered to be infected with viruses, and the absorbance values were used to estimate the virus titer. The average absorbance value of the extracts at the optimal dilution rate from 2 to 20 plants of the same treatment, depending on the number of infected plants, was taken as the relative level of virus accumulation in a plant at a timepoint. However, for samples with the absorbance values at the optimal dilution rate outside the proportional range, the value within the proportional range at another dilution rate was used to compute the average value after normalizing with the ratio of the actual dilution to the optimal dilution. The same preparations of antibodies against RTBV and RTSV were used throughout the experiments in this study for proper comparison among the results from different experiments. The apparent rate of infection with viruses is computed as (number of plants found infected by ELISA/number of inoculated plants) $\times 100(\%)$. The least significant difference test for the means was performed to evaluate the differences in the levels of virus accumulation at a timepoint among the test plants. The respective experiments were repeated twice.

\section{GLH free-choice test.}

To evaluate the levels of GLH preference among the test plants, host free-choice tests were conducted as described by Shibata and associates (2007). Five seedlings of a test plant were planted in a pot $(12 \mathrm{~cm}$ in diameter $)$. Two pots, each planted with the seedlings of a different test plant, were placed $10 \mathrm{~cm}$ apart in a cage ( 45 by 45 by $45 \mathrm{~cm}$ ). Fifty RTBV or RTSV viruliferous GLH were introduced inside the cage when the plants were 10 days old. The number of GLH that alighted on plants in each pot was recorded at $0.5,4,8$, and $24 \mathrm{~h}$ after introduction. Insects were removed at $24 \mathrm{~h}$ after infestation and plants were kept in the greenhouse. Plants were examined for infection with tungro viruses by ELISA at 20 days after GLH removal. The experiment was established in a complete randomized design with five replications. The experiment was repeated three times. The results were analyzed by a $\chi^{2}$ test.

\section{Microarray for RTSV-responsive genes.}

Genes whose expression levels change in response to RTSV infection in susceptible and resistant NIL derived from Utri Merah were examined by microarray analysis. Five seedlings per pot (12 cm in diameter) of TW16-4 (susceptible) or TW1669 (resistant) were grown in a temperature-controlled greenhouse $\left(27\right.$ to $\left.29^{\circ} \mathrm{C}\right)$. Seven-day-old seedlings were inoculated with three RTSV-viruliferous or virus-free GLH per seedling for $24 \mathrm{~h}$. At $7 \mathrm{dpi}$, the two youngest leaves were harvested from the individual plants and stored at $-70^{\circ} \mathrm{C}$. RNA samples were prepared from leaf samples pooled from three to five plants of the same treatment with TRIzol (Invitrogen, Carlsbad, CA, U.S.A.) according to the manufacturer's instructions. Comparisons of gene-expression patterns were made between TW16-4 (or -69) inoculated with virus-free GLH (mock) and that inoculated with RTSV-viruliferous GLH. Rice Oligo Microarray (G4138A; Agilent Technologies, Santa Clara, CA, U.S.A.) printed with 60-mer oligonucleotides deduced from approximately 21,500 full-length cDNA clones from rice cv. Nipponbare (Rice Full-Length cDNA Consortium 2003) was employed for the analysis. Labeling of RNA samples, processing of microarray slides, and data analysis were performed as previously described (Shimizu et al. 2007). Genes were declared significantly differentially expressed if i) the signal intensities of two samples compared were larger than 100, ii) the difference in expression between two samples was larger than 2 , and iii) the expression difference was significant at a $95 \%$ confidence level. The experiment was replicated twice with independent RNA samples. The microarray data used in this study (series number GSE14606) are available from the National Center for Biotechnology Information Gene Expression Omnibus database.

\section{RT-PCR for RTSV RNA.}

For preparation of leaf samples for detection of RTSV RNA by RT-PCR, 14-day-old plants of TN1 and TW16 were inoculated with RTSV as described above. The two youngest leaves were collected from the individual plants at 9 and $12 \mathrm{dpi}$, divided lengthwise nearly equally into three pieces, quickly frozen in liquid nitrogen, and kept at $-70^{\circ} \mathrm{C}$ until use. Infection of RTSV in the plants was examined by ELISA prior to RT-PCR. Total RNA was individually extracted from the divided leaves (Fig. 7) using TRIzol (Invitrogen) according to the manufacturer's instructions. RNA samples were reverse-transcribed using SuperScript III with an oligo(dT) primer (Invitrogen). PCR was carried out using Taq DNA polymerase (New England Biolabs, Ipswich, MA, U.S.A.) and RTSV-specific primers (forward primer 5'-GAAGAAGCCTATCATGTTCGCGT-3' and reverse primer 5'-CCTCCACGATATTGTACGAGG-3') targeted at a region of the coat protein cistron in the RTSV genome. The expected size of DNA fragment by RT-PCR is $787 \mathrm{bp}$. The amplified fragments were separated on $1.2 \%$ agarose gel and visualized by staining with ethidium bromide followed by viewing under UV transillumination.

\section{RT-PCR for virus-responsive genes.}

Among the genes whose expression patterns from microarray analysis were highly responsive to RTSV infection, nine were selected to examine their expression patterns by RTBV infection. Plants of TN1 and TW16 were mock- and RTBVinoculated by the Agrobacterium-mediated method. The two youngest leaves were collected from the individual plants at 3 , 7,14 , and 21 dpi. RNA samples were prepared from leaf samples pooled from four to five plants of the same treatment using Trizol. Plants were examined for infection with RTBV by ELISA prior to RT-PCR. First-strand cDNA fragments were produced from total RNA samples by SuperScript III reverse transcriptase with an oligo(dT) primer. The patterns of RTBVresponsive expression of the selected genes were examined by PCR of the cDNA samples using gene-specific primers usually targeted at the $3^{\prime}$ untranslated region. The numbers of amplification cycles were between 25 and 30, depending on the gene fragments to be amplified.

\section{Direct tissue-blotting immunoassay.}

Detection of viruses by direct tissue-blotting immunoassay was done as described by Lin and associates (1990) with some modifications. Sections were cut from fresh tissues of the sec- 
ond youngest leaf of virus-inoculated plants using a new razor blade for each sample. Tissue blots were prepared by pressing the newly cut surface onto $0.45-\mu \mathrm{m}$-pore-size nitrocellulose membrane (Bio-Rad Laboratories, Hercules, CA, U.S.A.) for 3 to $5 \mathrm{~s}$ with firm and gentle force. Blotted membranes were placed in a plastic container and blocked with $3 \%$ (wt/vol) nonfat milk powder dissolved in phosphate-buffered saline (PBS) for $60 \mathrm{~min}$ at room temperature. Membranes were then incubated with virus-specific primary antibodies diluted in PBS (RTBV immunoglobulin G [IgG] used at 1:1000 and RTSV IgG used at 4:1000) with gentle agitation at room temperature for $2 \mathrm{~h}$ or at $4^{\circ} \mathrm{C}$ overnight. Following three successive washings in PBS-Tween solution (PBS with $0.05 \%$ Tween 20) for 10 to $15 \mathrm{~min}$ each time, membranes were incubated with alkaline phosphatase-labeled secondary antibodies diluted in PBS (RTBV IgG used at 1:1000 and RTSV IgG used at 2:1000) at room temperature for $2 \mathrm{~h}$ or at $4^{\circ} \mathrm{C}$ overnight. Membranes were washed as described above and were then immersed in NBT-BCIP substrate solution (Sigma-Aldrich, St. Louis) for 5 to $10 \mathrm{~min}$ at room temperature. A positive result was indicated by the development of purple color on the tissue blot. The results were photographed using a dissecting scope with an optical magnification of $\times 8$ to 56 .

\section{ACKNOWLEDGMENTS}

This work was supported by International Collaborative Research Funds from the Rural Development Administration, Korea, and a Basic Research Activities for Innovative Biosciences grant from the Bio-oriented Technology Research Advancement Institution, Japan. We thank S. Kimura for supporting the microarray experiment and the Japan-IRRI project for providing the NIL used in this study.

\section{LITERATURE CITED}

Albar, L., Bangratz-Reyser, M., Hébrard, E., Ndjiondjop, M-N., Jones, M., and Ghesquière, A. 2006. Mutations in the eIF(iso)4G translation initiation factor confer high resistance to rice to Rice yellow mottle virus. Plant J. 47:417-426.

Anandalakshmi, R., Marathe, R., Ge, X., Herr, J. M., Jr., Mau, C., Mallory, A., Pruss, G., Bowman, L., and Vance, V. B. 2000. A calmodulin-related protein that suppresses posttranscriptional gene silencing in plants. Science 290:142-144.

Angeles, E. R., and Khush, G. S. 2000. Genetic analysis of resistance to green leafhopper, Nephotettix virescens (Distant) in three varieties of rice. Plant Breed. 119:446-448.

Azzam, O., and Chancellor, T. C. B. 2002. The biology, epidemiology, and management of rice tungro disease in Asia. Plant Dis. 86:88-100.

Azzam, O., Imbe, T., Ikeda, R., Nath, P. D., and Coloquio, E. 2001. Inheritance of resistance to Rice tungro spherical virus in a near-isogenic line derived from Utri Merah and in rice cultivar TKM6. Euphytica 122:91-97.

Bajet, N. B., Daquiaog, R. D., and Hibino, H. 1985. Enzyme-linked immunosorbent assay to diagnose rice tungro. J. Plant Prot. Trop. 2:125-129.

Cabauatan, P. Q., and Hibino, H. 1985. Transmission of rice tungro bacilliform and spherical viruses by Nephotettix virescens Distant. Philipp. Phytopathol. 21:103-109.

Cabauatan, P. Q., Cabunagan, R. C., and Koganezawa, H. 1995. Biological variants of rice tungro viruses in the Philippines. Phytopathology 85:7781.

Cabunagan, R. C., Angeles, E. R., Villareal, S., Azzam, O., Teng, P. S., Khush, G. S., Chancellor, T. C. B., Tiongco, E. R., Truong, X. H., Mancao, S., Astika, I. G. N., Muis, A., Chowdhury, A. K., Narasimhan, V., Ganapathy, T., and Subramanian, N. 1999. Multilocation evaluation of advanced breeding lines for resistance to rice tungro viruses. Pages 45-55 in: Rice Tungro Disease Management. T. C. B. Chancellor, O. Azzam, and K. L. Heong, eds. International Rice Research Institute, Manila, Philippines.

Chujo, T., Kato, T., Yamada, K., Takai, R., Akimoto-Tomiyama C., Minami, E., Nagamura, Y., Shibuya, N., Yasuda, M., Nakashita, H., Umemura, K., Okada, A., Okada, K., Nojiri, H., and Yamane, H. 2008. Characterization of an elicitor-induced rice WRKY gene, OsWRKY71. Biosci. Biotechnol. Biochem. 72:240-245.

Dahal, G., Hibino, H., Cabunagan, R. C., Tiongco, E. R., Flores, Z. M., and Aguiero, V. M. 1990. Changes in cultivar reaction totungro due to changes in "virulence" of the leafhopper vector. Phytopathology 80:659-665.

Dasgupta, I., Hull, R., Eastop, S., Poggi-Pollini, C., Blakebrough, M., Boulton, M. I., and Davies, J. W. 1991. Rice tungro bacilliform virus DNA independently infects rice after Agrobacterium-mediated transfer. J. Gen. Virol. 72:1215-1221.

Diaz-Pendon, J. A., Truniger, V., Nieto, C., Gracia-Mas, J., Bendahmane, A., and Aranda, M. A. 2004. Advances in understanding recessive resistance to plant viruses. Mol. Plant Pathol. 5:223-233.

Dong, J., Chen, C., and Chen Z. 2003. Expression profiles of the Arabidopsis WRKY gene superfamily during plant defense response. Plant Mol. Biol. 51:21-37.

Dubouzet, J. G., Sakuma, Y., Ito, Y., Kasuga, M., Dubouzet, E. G., Miura, S., Seki, M., Shinozaki, K., and Yamaguchi-Shinozaki, K. 2003. OsDREB genes in rice, Oryza sativa L., encode transcription activators that function in drought-, high-salt- and cold-responsive gene expression. Plant J. 33:751-763.

Ebron, L. A., Yumol, R. R., Ikeda, R., and Imbe, T. 1994. Inheritance of resistance to rice tungro spherical virus in some rice cultivars. Int. Rice Res. Notes 19:10-11.

Fauquet, C. M., Mayo, M. A., Maniloff, J., Desselberger, U., and Ball, L. A. 2005. Virus Taxonomy. Eight Report of the International Committee for the Taxonomy of Viruses. Academic Press, New York.

Feng, J.-X., Liu, D., Pan, Y., Gong, W., Ma, L.-G., Luo, J.-C., Deng, X. W., and Zhu, Y.-X. 2005. An annotation update via cDNA sequence analysis and comprehensive profiling of developmental, hormonal or environmental responsiveness of the Arabidopsis AP2/EREBP transcription factor gene family. Plant Mol. Biol. 59:853-868.

Gutterson, N., and Reuber, T. L. 2004. Regulation of disease resistance pathways by AP2/ERF transcription factors. Curr. Opin. Plant Biol. 7:465-471.

Hay, J. M., Jones, M. C., Blakebrough, M. L., Dasgupta, I., Davies, J. W., and Hull, R. 1991. An analysis of an infectious clone of rice tungro bacilliform virus, a plant pararetrovirus. Nucleic Acids Res. 19:2615-2621.

Hibino, H. 1983. Relations of rice tungro bacilliform and rice tungro spherical viruses with their vector Nephotettix virescens. Ann. Phytopathol. Soc. Jpn. 49:545-553.

Hibino, H., Roechan, M., and Sudarisman, S. 1978. Association of two types of virus particles with Penyakit Habang (tungro disease) of rice in Indonesia. Phytopathology 68:1412-1416.

Hibino, H., Tiongco, E. R., Cabunagan, R. C., and Flores, Z. M. 1987. Resistance to rice tungro-associated viruses in rice under experimental and natural conditions. Phytopathology 77:871-875.

Hibino, H., Daquiaog, R. D., Cabauatan, P. Q., and Dahal, G. 1988. Resistance to rice tungro spherical virus in rice. Plant Dis. 72:843-847.

Hibino, H., Daquiaog, R. D., Mesina, E. M., and Aguiero, V. M. 1990. Resistances in rice to tungro-associated viruses. Plant Dis. 74:923-926.

Hull, R. 1996. Molecular biology of rice tungro viruses. Annu. Rev. Phytopathol. 34:275-297.

Ito, Y., Katsura, K., Maruyama, K., Taji, T., Kobayashi, M., Seki, M., Shinozaki, K., and Yamaguchi-Shinozaki, K. 2006. Functional analysis of rice DREB1/CBF-type transcription factors involved in coldresponsive gene expression in transgenic rice. Plant Cell Physiol. 47:141-153.

Kang, B.-C., Yeam, I., and Jahn, M. M. 2005. Genetics of plant virus resistance. Annu. Rev. Phytopathol. 43:581-621.

Khush, G. S., Angeles, E., Virk, P. S., and Brar, D. S. 2004. Breeding rice for resistance to tungro virus at IRRI. SABRAO J. Breed. Genet. 36:101-106.

Lin, N. S., Hsu, Y. H., and Hsu, H. T. 1990. Immunological detection of plant viruses and a mycoplasma-like organism by direct tissue blotting on nitrocellulose membranes. Phytopathology 80:824-828.

Lin, R., Zhao, W., Meng, X., Wang, M., and Peng, Y. 2007. Rice gene OsNAC19 encodes a novel NAC-domain transcription factor and responds to infection by Magnaporthe grisea. Plant Sci. 172:120-130.

Lu, G., Jantasuriyarat, C., Zhou, B., and Wang, G.-L. 2004. Isolation and characterization of novel defense response genes involved in compatible and incompatible interactions between rice and Magnaporthe grisea. Theor. Appl. Genet. 108:525-534.

Rice Annotation Project. 2008. The Rice Annotation Project Database (RAP-DB): 2008 update. Nucleic Acids Res. 36:D1028-1033.

Rice Full-Length cDNA Consortium. 2003. Collection, mapping, and annotation of over 28,000 cDNA clones from japonica rice. Science 301:376-379.

Saika, H., Okamoto, M., Miyoshi, K., Kushiro, T., Shinoda, S., Jikumaru, Y., Fujimoto, M., Arikawa, T., Takahashi, H., Ando, M., Arimura, S., Miyao, A., Hirochika, H., Kamiya, Y., Tsutsumi, N., Nambara, E., and Nakazono, M. 2007. Ethylene promotes submergence-induced expression of OsABA8ox1, a gene that encodes ABA 8'-hydroxylase in rice. Plant Cell Physiol. 48:287-298. 
Sebastian, L. S., Ikeda, R., Huang, N., Imbe, T., Coffman, W. R., and McCouch, S. R. 1996. Molecular mapping of resistance genes to rice tungro spherical virus and green leafhopper in rice. Phytopathology 86:25-30.

Shahjahan, M., Jalant, A. H., Zakri, A. H., Imbe, T., and Othman, O. 1990. Inheritance of tolerance to rice tungro bacilliform virus (RTBV) in rice (Oryza sativa L.). Theor. Appl. Genet. 80:513-517.

Shen, P., Kaniewska, M., Smith, C., and Beachy, R. N. 1993. Nucleotide sequence and genomic organization of rice tungro spherical virus. Virology 193:621-630.

Shibata, Y., Cabunagan, R. C., Cabauatan, P. Q., and Choi, I.-R. 2007. Characterization of Oryza rufipogon-derived resistance to tungro disease in rice. Plant Dis. 91:1386-1391.

Shimizu, T., Satoh, K., Kikuchi, S., and Omura, T. 2007. The repression of cell wall- and plastid-related genes and the induction of defense-related genes in rice plants infected with Rice dwarf virus. Mol. Plant-Microbe Interact. 20:247-254.

Sta. Cruz, F. C., Boulton, M. L., Hull, R., and Azzam, O. 1999. Agroinoculation allows the screening of rice for resistance to rice tungro bacilliform virus. J. Phytopathol. 147:653-659.
Sta. Cruz, F. C., Hull, R., and Azzam, O. 2003. Changes in the level of virus accumulation and incidence of infection are critical in the characterization of Rice tungro bacilliform virus (RTBV) resistance in rice. Arch. Virol. 148:1465-1483.

Zenna, N. S., Sta. Cruz, F. C., Javier, E. L., Duka, I. A., Barrion, A. A., and Azzam, O. 2006. Genetic analysis of tolerance to Rice tungro bacilliform virus in rice (Oryza sativa L.) through agroinoculation. J. Phytopathol. 154:197-203.

Zenna, N. S., Cabauatan, P. Q., Baraoidan, M., Leung, H., and Choi, I.-R 2008. Characterization of a putative rice mutant for reaction to rice tungro disease. Crop Sci. 48:480-486.

\section{AUTHOR-RECOMMENDED INTERNET RESOURCES}

National Center for Biotechnology Information Gene Expression Omnibus database: www.ncbi.nlm.nih.gov/geo

Knowledge-based Oryza Molecular Biological Encyclopedia (KOME): cdna01.dna.affrc.go.jp/cDNA/)

Rice Annotation Project database: rapdb.dna.affrc.go.jp 